\title{
THE EFFECTIVENESS OF THE E-LEARNING FROM THE PERSPECTIVES OF UNIVERSITY STUDENTS ON THE ACCEPTANCE, ACCESSIBILITY AND COST SAVINGS
}

\author{
Zuhal Hussein \\ Faculty of Business Management, Universiti Teknologi MARA, Kota Bharu, Kelantan, Malaysia \\ zuhal@kelantan.uitm.edu.my
}

\begin{abstract}
The evolution and the internationalization of education system, has made the learning process easier and flexible. Over the past few years, E-Learning has evolved with demand from an increasing number of countries that transform the academic policy in order to produce highly educated community. Electronic learning (E-Learning) is learning utilizing electronic technologies to access educational curriculum outside of a traditional classroom. In most cases it refers to a course or program or degree delivered completely online. To be competitive and cost efficient, higher learning institutions are struggling to adapt an E-Learning approach. As such E-Learning has struggled to find acceptance in academic circles. Thus, this study aims to explore the effectiveness of E-Learning from three variables which are acceptance, accessibility and the cost savings. This study recruited 315 university students through random sampling. Data were collected through survey. The respondents were asked for consent before proceeding to the survey in order to ensure that ethical consideration was taken into account during conducting the study. Data were analysed using statistical package of social sciences (SPSS) and various statistical techniques were used such as descriptive analysis and regression analysis. Results indicate that there was a significant relationship between acceptance and the effectiveness of E-Learning, while it was different for the accessibility and cost savings. The result also found that acceptance is an important factor that contributes to the effectiveness of E-Learning with a value of $\beta=0.982$. In conclusion, it is time to improve the E-Learning system through access to mobiles and moving towards a new educational paradigm called 'M-Learning'.
\end{abstract}

Keywords: E-learning, acceptance, accessibility, cost saving, effectiveness

\section{INTRODUCTION}

The evolution and the internationalization of education system, has made the learning process easier and flexible. Over the past few years, E-Learning has evolved with demand from an increasing number of countries that rely on Internet services. E-Learning can be a factor in changing the environment from brick to 
click. E-Learning is learning utilizing electronic technologies to access educational curriculum outside of a traditional classroom. In most cases, it refers to a course, program or degree delivered completely online. Elearning as a "way of teaching and learning" moving towards a "new educational paradigm"(Sangra, Vlachopoulos and Cabrera, 2012). However, as a tool of new educational paradigm, E-Learning has struggled to be accepted in academic circles. Eom (2006) posited that studying via online is not for everyone because they might find it hard to motivate themselves or difficult to study at home. In spite of the tremendous opportunities afforded by e-learning for learners, there are a variety of barriers that interfere with their effective use. Mostly student feel inconvenience using E-Learning platforms because they feel that the system will always bring a problem to them such as complicated programme. Besides, the acceptance will be slightly problematic because the students will be more lenient about their assessment and exposed to cheating.

In addition, studies by Konur (2007) and Waddell (2007) imposed a question on how accessible is the growing array of available e-learning for on campus and off campus students. Despite online courses allowing students to complete coursework from a wide range of locations and remove the time restriction to access course lectures, however, not all students can afford to have access or subscribe to broadband or Wifi connection at their accommodation because they come from a different socio-economic background and exposure.

Another common myth about online courses is that it can reduce cost and energy. However, if not implemented correctly, it can also be a colossal waste of time and money. In reality, students have to spend more money on printing paper, paying for internet, utilities and other expenses in order to access E-Learning facilities (Arsham, 1995).

Therefore in order to fill this gap, it is crucial to explore the effectiveness of E-Learning through the critical variables of acceptance, accessibility and cost savings.

\section{LITERATURE REVIEW}

\subsection{Effectiveness of E-Learning}

From the perspective of Bloom's Taxanomy, e-learning is an effective learning tool (Halawi et al. 2009). A study by Chan et al (2007) stated that the effectiveness of E-Learning is based on the convenience and portability as students can access it anywhere and at any time. According to Elizabeth et al (2002), the effectiveness of E-Learning is also based on cost saving measure. The potential cost savings are indirect which that occurs because students using e-learning may require less time to learn than those who learn in a classroom.

\subsection{Acceptance}

A study by Dillon and Morris (1996) defines students' acceptance as "the demonstrable willingness within a user group to employ information technology for the tasks it is designed to support". A study by Song (2010) strengthened the critical need of e-learning which is highly associated with the technology application, as such learners' technology acceptance will play a crucial part in contributing to the success of online learning programs. This study, viewed acceptance in the context of acceptance of technology which refers to online courses which users adapt to, as well as the service as a useful tool in improving their performance in learning. According to previous studies (Hong, Lai and Holton, 2003; Khalid, 2014; Hussein, 2015), the students who had a high level of acceptance indicated that E-Learning was convenient and flexible. When users of e-learning believe using the online course improves their productivity and effectiveness, they are likely to accept and consider taking the online course.

$\mathrm{H} 1$ : There is a significant and positive relationship between acceptance and the effectiveness of E-Learning.

\subsection{Accessibility}

In this study, e-learning accessibility refers to the degree of ease with which a university student can access and use a campus e-learning system (Thong, Hong, and Tam, 2002). Accessibility is crucial as the learning process has to take place through the Internet. Without it being easily accessible, learners will easily lose their patience and find this learning method becoming less convenient for them. One of the benefits of ELearning is that it provides a fast and easy learning environment (Chai and Poh, 2009). Lin and Lu (2000) reported that higher information accessibility brings about higher use of information and higher perception of use, and which will highlight the effectiveness of the online system.

$\mathrm{H} 2$ : There is a significant and positive relationship between accessibility and the effectiveness of E-Learning. 


\subsection{Cost saving}

According to Hjeltnes \& Hansson (2005), if a learning program is effective, it has the potential of being cost effective. Ashram (1995) stated that online learning can be more effective than classroom, and it is becoming less expensive too. He also mentioned that one of the main concerns in targeting the transformation of learning/teaching through technology is by reducing the cost. Ideally, e-Learning is the least costly education option (Woddall, 2011). It not only saves cost, work hours and the facility's energy, but the information is maintained and updated much more effectively online as well.

H3: There is a significant and positive relationship between cost savings and the effectiveness of E-Learning.

\section{METHODOLOGY}

This quantitative study involves 315 university students of Public Higher Institution (IPTA) in Kelantan. The respondents were selected randomly through the probability sampling technique. A survey method was used as an approach in this study and a structured questionnaire was given to a sample of a population to collect information from respondents. The questionnaire was given to the respondents with a time allocation of around 20 minutes to complete the questionnaire. The questionnaire includes the explanation of the purpose of the study and the instructions to the respondent at the front page and followed by five sections which are socio demographic profiles; and the Likert-scale, designed to address questions on effectiveness, acceptance, accessibility and cost savings. The respondents were asked for consent before proceeding to the survey in order to ensure that ethical consideration was taken into account during conducting the study. Lastly, data were analyzed using statistical package of social sciences (SPSS) and statistical techniques were used such as descriptive analysis and regression analysis.

\section{RESULTS}

The profile of the respondents were shown in Table 1

Table 1: Profile of the Respondents

\begin{tabular}{|l|l|l|}
\hline Profile & Categories & Percentage (\%) \\
\hline Gender & Male & 40.3 \\
& Female & 59.7 \\
\hline Age (Years) & $20-23$ & 58.7 \\
& $24-27$ & 27.3 \\
& $28-31$ & 14.0 \\
\hline Education & Bachelor & 96.5 \\
level & Master & 3.5 \\
\hline Area of study & Economics & 34.9 \\
& Finance & 23.5 \\
& Marketing & 20.0 \\
& Islamic Banking & 12.7 \\
& Statistics & 8.9 \\
\hline Semester & 1 & 34.9 \\
& 2 & 26.0 \\
& 3 & 24.8 \\
& 4 & 12.4 \\
\hline
\end{tabular}

Table 1 presents the distribution of the respondents based on gender, age groups, level of education, course and semester of the study. In terms of gender, the percentage of female respondents is slightly higher, which accounts for more than half of the total respondents surveyed (59.7\%) and compared to male respondents $(40.3 \%)$. Majority of the respondents were in the age range $20-23$ years $(58.7 \%)$, followed by those between 24-27 years (27.3\%) and the least was the age group of 28-31 years (14\%). In terms of education level, majority of the respondents surveyed were studying for their bachelor's degree $(96.5 \%)$, which accounts for more than $90 \%$ of the total respondents and the lowest was found among to studying for their master's degree (3.5\%). Most of the respondents were studying in Economic courses (34.9\%), followed by Finance courses $(23.5 \%)$, Marketing courses (20.0\%), Islamic Banking course (12.7\%) and lastly Statistic course $(8.9 \%)$. Majority of the students were in semester 1 (34.9\%), followed by the students in Semester $2(26.0 \%)$ and lastly students in Semester 3 (24.8\%). 
Table 2: Regression analysis of Coefficients

\begin{tabular}{|c|c|c|c|c|c|}
\hline \multirow[t]{3}{*}{ Model } & \multirow{2}{*}{\multicolumn{3}{|c|}{ Unstandardized Standardized }} & \multirow[t]{3}{*}{$\mathrm{t}$} & \multirow[t]{3}{*}{ Sig. } \\
\hline & & & & & \\
\hline & $\beta$ & $\begin{array}{l}\text { Std. } \\
\text { Error }\end{array}$ & Beta & & \\
\hline (Constant) & 301 & .086 & & 3.483 & .001 \\
\hline Accessibility & -.016 & .035 & -.017 & -.454 & 650 \\
\hline Acceptance & .982 & .043 & .983 & 23.100 & .000 \\
\hline Cut cost & -.051 & .042 & -.049 & -1.195 & .233 \\
\hline
\end{tabular}

a. Dependent variable: Effectiveness

According to the result above, acceptance item is significant with the effectiveness of E-Learning by having $p$-value $=0.000$ whilst accessibility and cost saving are not significant with effectiveness. The result also found that acceptance is the important factor that contributes to the effectiveness of E-Learning with a value of $\beta=0.982$. The results indicate that they have a positive relationship with each other. The relationship can be defined by when a factor goes up $1 \%$, then effectiveness also increases by $\beta \%$ while other variables are held constant.

\section{DISCUSSION AND CONCLUSION}

From the findings, the study found the factors that influence the effectiveness of E-Learning among university students. This study indicates that acceptance is an important and significant factor to be associated with the effectiveness of E-Learning. This result is similar to a previous study done by Hong, Lai and Holton (2003), who reported that more than half of their participants had high levels of acceptance with the E-Learning. This is due to the fact that students have to accept and already aware about the E-Learning. Students were exposed to online learning since they were in Year 1. They found that E-Learning was convenient and flexible for them. According to (Hussein, 2015; Khalid, 2014), students have accepted ELearning because it was convenient for them, and they can learn at their own pace and its flexible in terms of time and place.

In terms of accessibility, the findings of this study found nothing significant with regards to the effectiveness of the E-Learning. Majority of the previous studies in E-Learning that focus on the accessibility factor which is significant when associated with disable students (Ssegawa, 2015; Guglielman, 2010; Ficthen et al, 2009). This is due to the fact that this study employed the able students and they feel that they do not have a problem accessing the online facilities either physically or mentally. Cost saving also was not a significant factor that contributed to the effectiveness of the E-Learning. Students do not have a problem with this issue because basically, the university has already provided the online facilities and internet access freely to all university students in the campus (Hjeltnes \& Hansson, 2005).

In conclusion, since the acceptance is the most important factor that contributes to the effectiveness of $\mathrm{E}$ Learning, therefore it shows that E-Learning is already accepted by the university students who are the generation of technology savvy people including having a smartphone and it is timely for improving the accessibility of the online learning system through mobile and moving towards a new educational paradigm called 'M-Learning'.

\section{REFERENCE LIST}

Arsham, H. (1995). Interactive Education: Impact of the Internet on Learning \& Teaching. http://home.ubalt.edu/ntsbarsh/interactive.htm

Chai Lee Goi \& Poh Yen Ng.(2009). E-learning in Malaysia: Success Factors in Implementing E-learning Program. Paper presented at International Journal of Teaching and Learning in Higher Education. 20(2), pp 237-246.

Chan Y. F., Ranjit K.S., Jamiah Baba \& Eliza Parman. (2007). Computer Education for Classroom Teaching. Malaysia: McGraw-Hill 
Dillon, A., \& Morris, M. G. (1996). User acceptance of information technology: Theories and models. Annual Review of Information Science and Technology, 31, 3-32

Eom,L. (2006).

Fichten, C. S. Ferraro, V. Asuncion, J. V. Chwojka, C. Barile, M. Nguyen, M. N. Klomp, R. \& Wolforth, J. (2009). Disabilities and e-Learning Problems and Solutions: An Exploratory Study. Educational Technology \& Society, 12(4), 241-256. http://www.adaptech.org/cfichten/abDisabilitiesAndELearningProblems.pdf

Guglielman, E. (2010). E-Learning and Disability: Accessibility as a contributor to inclusion. Fifth Doctoral Consortium at the European Conference on Technology Enhanced Learning, Barcelona, Spain, 29 September, 31-36

Halawi, L.A., Mccarthy, R.V \& Pires, S. (2009) An Evaluation of E-learning on the Basis of Bloom's Taxonomy: An Exploratory Study. Journal of Education for Business, 84 (6), 374-380.

Hussein, Z. (2015). Explicating students' behaviours of E-learning: A viewpoint of the extended technology acceptance. International Journal of Management and Applied Science, 1 (10), pp 68-73.

Hjeltnes,T.A. \& Hansson,B.(2005). Cost effectiveness and cost efficiency in E-Learning.QUIS

Hong, K.S., Lai, K.W., \& Holton, D. (2003). Students' satisfaction and perceived learning with a Webbased course. Journal of Educational Technology \& Society 6(1). Retrieved January 15, 2004, from http://ifets.ieee.org/periodical/vol 1 2003/v 1 2003.html.

Khalid, N. (2014). The Role of Perceived Usefulness And Perceived Enjoyment In Assessing Students' Intention To Use Lms Using 3-Tum. Global Summit on Education GSE 2014 (E-ISBN 978-11768-5-6)

Konur, O. (2007) Computer assisted teaching and assessment of disabled students. Journal of Computer Assisted Learning, 23,207-21

Lin, J.C.-C., Lu, H., 2000. Towards an understanding of the behavioural intention to use a Web Site. International Journal of Information Management 20, 197-208.

Sangra, A., Vlachopoulos, D., \& Cabrera, N. (2012). Building an Inclusive Definition of E-Learning: An Approach to the Conceptual Framework. The International Review of Research in Open and Distributed Learning.

Song, S.M. (2010). E-learning: Investigating students' acceptance of online learning in hospitality programs. Masters' Thesis.

Ssegawa, A. (2015). An analysis of accessibility of e-Learning Systems in the context of Higher Education in Uganda (2015-2016)

Thong, J. Y. L., Hong, W., Tam, K. (2002). Understanding user acceptance of digital libraries: What are the roles of interface characteristics, organizational context, and individual differences? International Journal of Human-Computer Studies, 57, 215- 242

Waddell, C. D. (2007). Accessible electronic \& information technology: Legal obligations of higher education and Section 508. ATHEN e-Journal, 2, retrieved May 3, 2009, from http://athenpro.org/node/54.

Woodall, L,C. (2011). "Transitioning to Online Education in the Caribbean: The UWI Open Campus." University of Toronto: Ph.D. dissertation.

https://tspace.library.utoronto.ca/bitstream/1807/29938/1/Woodall_Lora_C_20117_PhD_thesis.pdf 